\title{
ORIGINAL
}

\section{Genotyping of Heterogenous Osteopetrotic Mice Using Microsatellite Markers}

\author{
Yoshinobu Asada, Yukie Sato*, Takehiko Shimizu**, Toshiro Sakae*** \\ Hirotsugu Yamamoto* and Takahide Maeda** \\ Department of Pediatric Dentistry, Tsurumi University School of Dental Medicine \\ *Department of Pathology, Nihon University School of Dentistry at Matsudo \\ **Department of Pediatric Dentistry, Nihon University School of Dentistry at Matsudo \\ ${ }^{* * *}$ Department of Anatomy, Nihon University School of Dentistry at Matsudo \\ 2-1-3 Tsurumi, Tsurumi-ku, Yokohama 230-8501, Japan \\ *,******2-870-1 Sakaecho-Nishi, Matsudo 271-8587, Japan
}

(Received on July 30, 2001 ; Accepted on October 19, 2001)

Key words : osteopetrosis/op mouse/microsatellite marker

\begin{abstract}
The aim of this study was to elucidate the three genotypes $(o p / o p, o p /+$ and $+/+)$ of heterogenous osteopetrotic mice using microsatellite markers. The genotyping analysis was performed on genetic crosses using B6C3Fe-op/+ and A/WySnJ mice. In this study, we used five MIT markers, D3Mit11, 75, 101, 102 and 189 that are closely linked to the $o p$ locus and which segregate polymorphic variants in mating between $\mathrm{B} 6 \mathrm{C} 3 \mathrm{Fe}-o p /+$ and $\mathrm{A} / \mathrm{WySnJ}$ mice, and the homozygous $o p / o p \mathrm{~F} 3$ mice were obtained by $\mathrm{F} 2$ mice mating. From the results of F3 genotyping, it was possible to determine the genotype of the $o p$ gene without a complicated molecular process. Histopathological studies revealed that the F3-op/op mice showed similar femur bone structures to those of $\mathrm{B} 6 \mathrm{C} 3 \mathrm{Fe}-o p / o p$ mice. Based on these findings, it is suggested that genotyping of heterogenous osteopetrotic mice using microsatellite markers is a powerful technique for investigating the mechanism of osteoclast development and genetic studies of osteopetrosis.
\end{abstract}

抄録：大理石骨病交雑系モデルマウスを用い, マイクロサテライトマーカーによる遺伝子型を検出することで $o p$ 遺伝子の 3 つの遺伝子型 $(o p / o p, o p /+,+/+)$ を判定できるか否かを目的とし本実験を行った。 $\mathrm{B} 6 \mathrm{C} 3 \mathrm{Fe}-$ $o p /+$ ウスと A/WySnJ マウスとの交配より得られたすべての F2 マウスの遺伝子型をマイクロサテライト マーカーにて判定したところ，すべてのマウスで表現型（切歯の萌出の有無）と一致していた。さらに，肉眼的 には+/+と判別困難なへテロ型 $(o p /+)$ マウスをマイクロサテライトマーカーより判定し, 選抜した F 2 へテロ 型マウス雌雄を交配したところ，F 3 マウスにおいて op/op マウスを作成することができた。また, 組織学的所見 より従来の op マウスと F 3-op/op マウスでは大腿骨における形態学的特徵が類似していた。以上の結果より, 大 理石骨病交雑系モデルマウスはマイクロサテライトマーカーを用いることで簡便に遺伝子型を判定できることが 明らかとなり，破骨細胞の分化に対するメカニズム解明ならびに大理石骨病の遺伝学的研究に有用であることが 示唆された。

\section{Introduction}

Osteopetrosis is well known as an autosomal recessive disease in several species, including $\operatorname{man}^{1,2)}$. In mice, the osteopetrosis (op) occurred spontaneously in the $\mathrm{C} 57 \mathrm{BL} / 6 \mathrm{~J}-d w$ (dwarf, recessive gene) stock. The osteopetrotic $(o p / o p)$ mutant mouse is characterized by reduced numbers of osteoclasts, macrophages and monocytes $^{3}$. The op mouse is an important animal model for investigating the histopathology of the interactions between the alveolar bone and impacted 
dental germs. In fact, the mutant $o p / o p$ mouse can be recognized clearly at 10 days of age by failure of tooth eruption and separated from the wild type control $(+/+, o p /+)$ at weaning. However, it has not been possible to differentiate between $o p /+$ and $+/+$ as heterozygous and homozygous because of the recessive mutation of the $o p$ gene. Recent studies showed that the changing of structure and composition of bone in osteopetrotic mice were associated with their genotype ${ }^{4,5)}$. To detect the genotype of the $o p$ gene, a new strain of osteopetrotic mouse was produced by mating $\mathrm{B} 6 \mathrm{C} 3 \mathrm{Fe}-o p /+$ mice and $\mathrm{A} / \mathrm{WySnJ}$ mice. It has been demonstrated that this heterogenous osteopetrotic mouse is useful for investigating the histopathological study of osteopetrosis ${ }^{6}$. Recently, some informative microsatellite markers were found as the flanking markers for the $o p$ gene $^{7}$. The aim of this study was to elucidate the three genotypes $(o p)$ $o p, \quad o p /+$ and $+/+$ ) of heterogenous osteopetrotic mice using the microsatellite markers.

\section{Materials and Methods}

\section{Experimental design}

B6C3Fe- $o p /+$ mice were purchased from CLEA Japan Inc. (Tokyo, Japan). A/WySnJ were obtained from the National Institute of Genetics (Shizuoka, Japan). (B6C3Fe-op $/+$ female $\times \mathrm{A} / \mathrm{WySnJ}$ male) $\mathrm{F} 1$, the $\mathrm{F} 2$ intercross ( $\mathrm{F} 1$ female $\times \mathrm{F} 1$ male) and the $\mathrm{F} 3$ intercross ( $\mathrm{F} 2$ female $\times \mathrm{F} 2$ male) were obtained by mating the mice in our laboratory. The F1 mice were mated randomly and half of the normal offspring are expected to be $\mathrm{op}^{o p} / \mathrm{A}^{+}$and half $\mathrm{op}^{+} / \mathrm{A}^{+}$, the two classes being indistinguishable. Homozygous osteopetrotic $\mathrm{op}^{o p} / \mathrm{op}^{o p}$ mice can be clearly distinguished from their normal siblings by the absence of incisors. If we find the affected (non-eruption of incisors) mice in the $\mathrm{F} 2$ line, their parent $\mathrm{F} 1$ mice are heterozygotes $\left(o p^{o p} / \mathrm{A}^{+}\right)$for $o p$ mutant alleles. The homozygous $\mathrm{op}^{o p} / \mathrm{op}^{o p} \mathrm{~F} 3$ mice were produced by the F2 mice, which are hypothesis heterozygotes $\left(\mathrm{op}^{o p} /\right.$ $\mathrm{A}^{+}$). All mice were maintained in a conventional environment in the Nihon University School of Dentistry at Matsudo Dental Center Animal Facility according to the guidelines of the Animal Use and
Care Committee.

\section{DNA}

DNA samples were prepared from the spleen of parents ( $\mathrm{B} 6 \mathrm{C} 3 \mathrm{Fe}-o p /+$ and $\mathrm{A} / \mathrm{WySnJ}), \mathrm{F} 1$ hybrids, and F3 intercross mice. A DNA sample of F2 intercross mice was prepared from the orbital sinuses because of hypothesis genetic mating. DNA extraction was carried out as described by Nomura, et al ${ }^{8}{ }^{8}$.

\section{Polymerase chain reaction conditions}

A thermalcycler 480 (TaKaRa, Tokyo, Japan) was used for polymerase chain reaction (PCR). The reagents and PCR conditions were performed as described by Asada, et al. ${ }^{9}$. PCR products were electrophoresed in $8 \%$ polyacrylamide gels (running buffer : $1 \times \mathrm{TBE})$ at $100 \mathrm{~V}$ for $1.5 \mathrm{~h}$. The gels were stained with ethidium bromide for $8 \mathrm{~min}$. PCR products were examined in ultraviolet light and photographed.

\section{Simple sequence-length polymorphism markers}

The microsatellite marker used in this study is one of the most useful SSLP markers in genetic research $^{10-12)}$. MIT primers for microsatellite loci were purchased from Research Genetics Inc. (Boston, MA). MIT markers, D3Mit11, 75, 101, 102 and 189, used in this study have been determined as informative markers, being polymorphisms between C57BL/ $6 \mathrm{~J}$ and $\mathrm{A} / \mathrm{WySnJ}$. Also, these markers have been mapped near the osteopetrosis $(o p)$ gene $^{7,12)}$.

\section{Detection of the hypothesis genotype}

SSLP typing of F2 and F3 mice was performed using informative markers on the mouse chromosome 3 in order to detect the hypothesis genotype against the $o p$ gene. Illustration of the link between the $o p$ locus and MIT marker is shown in Fig. 1. Since the five MIT markers used in this study were closely linked to the $o p$ gene, the probability of interchromosomal recombination occurring between the two loci would be very low. Hence it allows that the hypothesis genotype of $\mathrm{F} 2$ and $\mathrm{F} 3$ mice is evaluated by SSLP typing. 


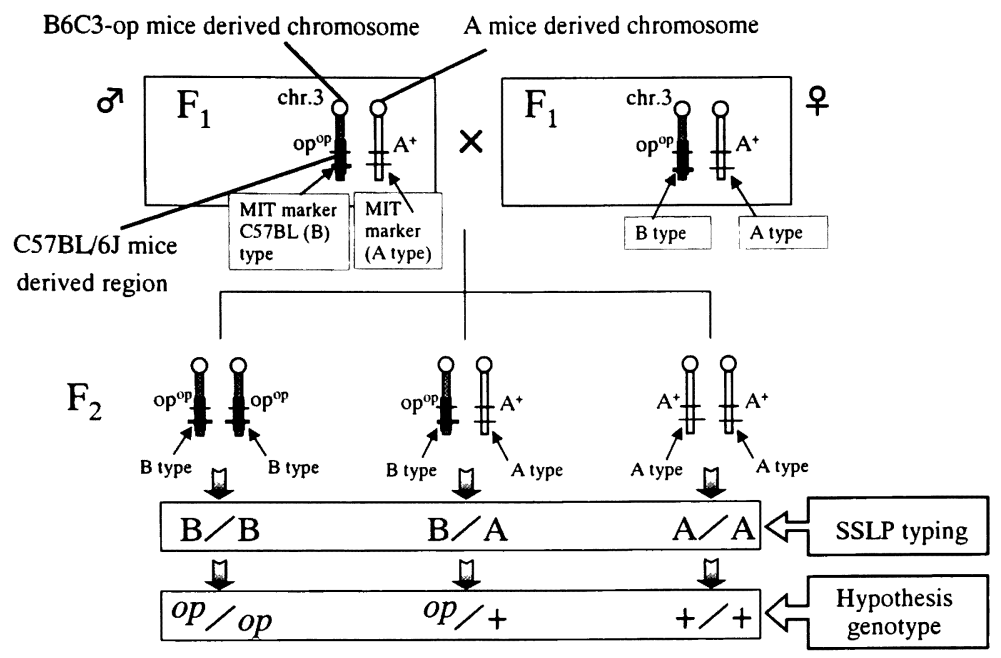

Fig. 1 Illustration of the link between $o p$ locus and MIT marker.

\section{Estimate of incisor eruption}

Homozygous osteopetrotic mice were evaluated by the absence of incisors eruption, according to the previous study ${ }^{6}$.

\section{Histology}

In our experiment, the determination of the genotype of the F3-op/op was evaluated by the absence of incisor eruption. Osteopetrotic $(o p / o p)$ mice were obtained from $\mathrm{B} 6 \mathrm{C} 3 \mathrm{Fe}-o p /+$ breeding pairs and were used as histological controls. The F3$O D / O D$ mice and $O p / O D$ mice were killed 24 days after birth. Femurs were removed and fixed with $10 \%$ neutral buffered formalin in $0.1 \mathrm{M}$ phosphate buffer (pH 7.4) for 4 days. They were demineralized in $10 \%$ sodium format-citrate for 2 weeks at $4^{\circ} \mathrm{C}$. For hematoxylin-eosin (H.E.) staining, the femurs were embedded in paraffin by the usual method, and frontal sections of $4 \mu \mathrm{m}$ thick were made and stained with H. E. F 3-op/op and $o p / o p$ mice were evaluated by the morphological changes of cartilage continued to the trabecular bone in the femurs ${ }^{6,13)}$.

\section{Results}

\section{Individual genotyping}

The F2 (No. 1) mouse and F3 mice (Nos. 7, 8 and 10) had no incisor eruption and their genotypes were evaluated by a complete phenotype (Fig. 2).

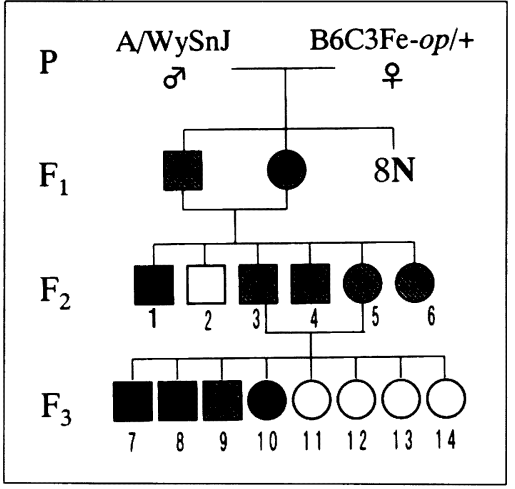

Fig. 2 Pedigrees of families with a new strain of osteopetrotic mice.

: Heterozygous male mouse $\left(\mathrm{op}^{o p} / \mathrm{A}^{+}\right)$.

: Heterozygous female mouse $\left(\mathrm{op}^{o p} / \mathrm{A}^{+}\right)$.

: Homozygous male mouse $\left(\mathrm{op}^{o p} / \mathrm{op}^{o p}\right)$.

: Homozygous female mouse $\left(\mathrm{op}^{o p} / \mathrm{op}^{o p}\right)$.

$\square$ : Homozygous male mouse $\left(\mathrm{A}^{+} / \mathrm{A}^{+}\right)$.

$\bigcirc$ : Homozygous female mouse $\left(\mathrm{A}^{+} / \mathrm{A}^{+}\right)$.

The designations in brackets are individual recognition.

$\mathrm{N}$ : Incisor erupted normal littermate mouse $\left(\mathrm{op}^{o p} / \mathrm{A}^{+}\right.$or $\left.\mathrm{op}^{+} / \mathrm{A}^{+}\right)$.

Individual genotyping of 6 F2 mice (Nos. 1-6) and 8 F3 mice (Nos. 7-14) was performed using SSLP analysis. The SSLP typing at D3Mit11 and D3Mit101 is shown in Fig. 3. As shown in Table 1, the hypothesis genotyping of F2 and F3 mice was performed by SSLP typing with MIT markers and compared with their phenotype. No genotype was in conflict with its 

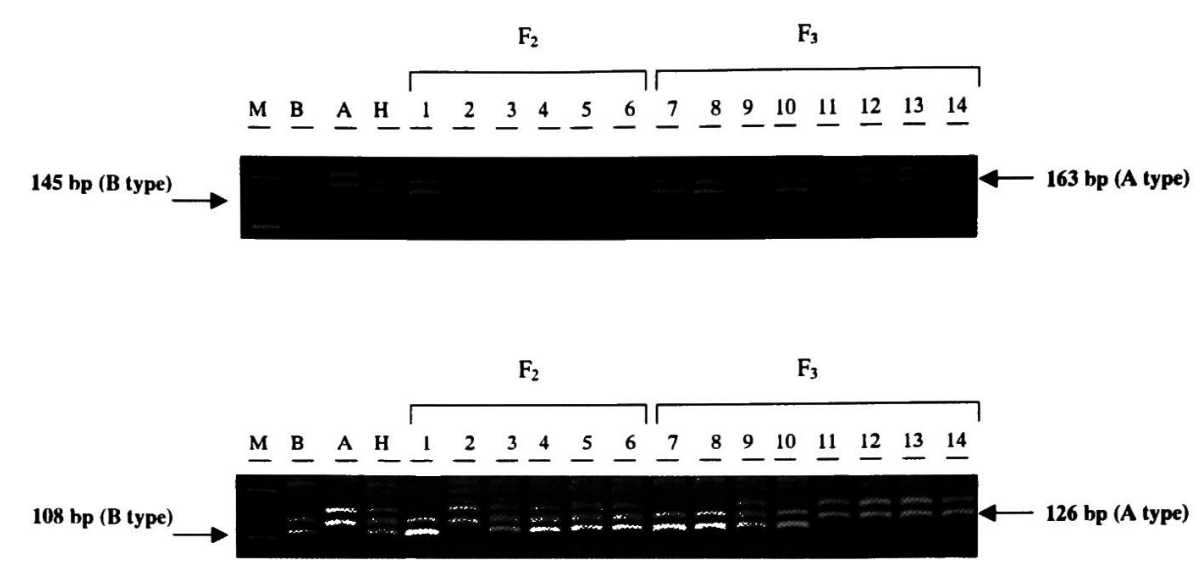

Fig. 3 SSLP typing of F2 and F3 mice using MIT primers (Top ; D3Mit11, bottom ; D3Mit101). PCR products were electrophoresed in $8 \%$ polyacrylamide gels. Odd lanes indicate expected PCR products (A ; A/WySnJ mice, $\mathrm{B} ; \mathrm{C} 57 \mathrm{BL} / 6 \mathrm{~J}$ mice, $\mathrm{H} ; 1: 1$ mix controls). The sample number corresponds to the pedigree chart. $\mathrm{M}:$ molecular size marker ( $100 \mathrm{bp}$ DNA ladder).

Table 1 Detection of the hypothesis genotype using MIT markers

\begin{tabular}{|c|c|c|c|c|c|c|c|c|}
\hline \multirow{2}{*}{ Strain } & \multirow{2}{*}{ Sex } & \multicolumn{5}{|c|}{ SSLP typing with MIT marker } & \multirow{2}{*}{$\begin{array}{l}\text { Hypothesis } \\
\text { genotype }\end{array}$} & \multirow{2}{*}{$\begin{array}{l}\text { Eruption of } \\
\text { incisors }\end{array}$} \\
\hline & & 11 & 75 & 101 & 102 & 189 & & \\
\hline $\mathrm{F}_{2}$ (No. 1) & M & ${ }^{*} \mathrm{~B}$ & $\mathrm{~B}$ & $\mathrm{~B}$ & $\mathrm{~B}$ & B & $o p / o p$ & non-eruption \\
\hline $\mathrm{F}_{2}$ (No. 2) & M & ${ }^{* *} \mathrm{~A}$ & A & $\mathrm{A}$ & A & A & $+/+$ & normal \\
\hline $\mathrm{F}_{2}$ (No. 3) & M & ${ }^{* * *} \mathrm{H}$ & $\mathrm{H}$ & $\mathrm{H}$ & $\mathrm{H}$ & $\mathrm{H}$ & $o p /+$ & normal \\
\hline $\mathrm{F}_{2}$ (No. 4$)$ & M & $\mathrm{H}$ & $\mathrm{H}$ & $\mathrm{H}$ & $\mathrm{H}$ & $\mathrm{H}$ & $o p /+$ & normal \\
\hline $\mathrm{F}_{2}$ (No. 5) & $\mathrm{F}$ & $\mathrm{H}$ & $\mathrm{H}$ & $\mathrm{H}$ & $\mathrm{H}$ & $\mathrm{H}$ & $o p /+$ & normal \\
\hline $\mathrm{F}_{2}$ (No.6) & $\mathrm{F}$ & $\mathrm{H}$ & $\mathrm{H}$ & $\mathrm{H}$ & $\mathrm{H}$ & $\mathrm{H}$ & $o p /+$ & normal \\
\hline $\mathrm{F}_{3}$ (No. 7) & M & B & B & B & B & B & $o p / o p$ & non-eruption \\
\hline $\mathrm{F}_{3}$ (No. 8) & M & B & B & B & B & B & $o p / o p$ & non-eruption \\
\hline $\mathrm{F}_{3}$ (No. 9) & M & $\mathrm{H}$ & $\mathrm{H}$ & $\mathrm{H}$ & $\mathrm{H}$ & $\mathrm{H}$ & $o p /+$ & normal \\
\hline $\mathrm{F}_{3} \quad($ No. 10$)$ & $\mathrm{F}$ & B & B & B & B & B & $o p / o p$ & non-eruption \\
\hline $\mathrm{F}_{3}($ No. 11) & $\mathrm{F}$ & A & A & A & A & $\mathrm{A}$ & $+/+$ & normal \\
\hline $\mathrm{F}_{3}$ (No. 12) & $\mathrm{F}$ & A & A & A & $\mathrm{A}$ & $\mathrm{A}$ & $+1+$ & normal \\
\hline$F_{3}$ (No. 13) & $\mathrm{F}$ & A & A & A & A & A & $+/+$ & normal \\
\hline$F_{3}$ (No. 14) & $\mathrm{F}$ & A & A & A & A & A & $+/+$ & normal \\
\hline
\end{tabular}

${ }^{*} \mathrm{~B}: \mathrm{C} 57 \mathrm{BL} / 6 \mathrm{~J}$ homozygote, ${ }^{* *} \mathrm{~A}: \mathrm{A} / \mathrm{WySnJ}$ homozygote, ${ }^{* * *} \mathrm{H}: \mathrm{A} / \mathrm{C} 57 \mathrm{BL}$ heterozygote

phenotype.

\section{Histology}

As shown in Fig. $4 \mathrm{a}-\mathrm{d}$, the femur of the F3-op/op mice and $\mathrm{B} 6 \mathrm{C} 3 \mathrm{Fe}-o p / o p$ mice had thin cortical bone, and reticular bone existed along the long axis. The development of the cortical bone and medullary cavity was immature, appearing as woven bone as seen in the immature stage (Fig. 4 c, d). From the epiphysis to the center of the diaphysis, cartilage existed around the trabecular bone and its appearance exhibited an unusual bi-concave or hourglass shape (Fig. $4 \mathrm{a}, \mathrm{b}$ ).

\section{Discussion}

Notable features in the $o p / o p$ mutant mouse such as skull deformation and tooth eruption failure are considered to be a result of defective bone resorption and remodeling ${ }^{14-16)}$. This is the result of the CSF-1 gene mutation, and $o p / o p$ mice are cured by CSF-1 injec- 


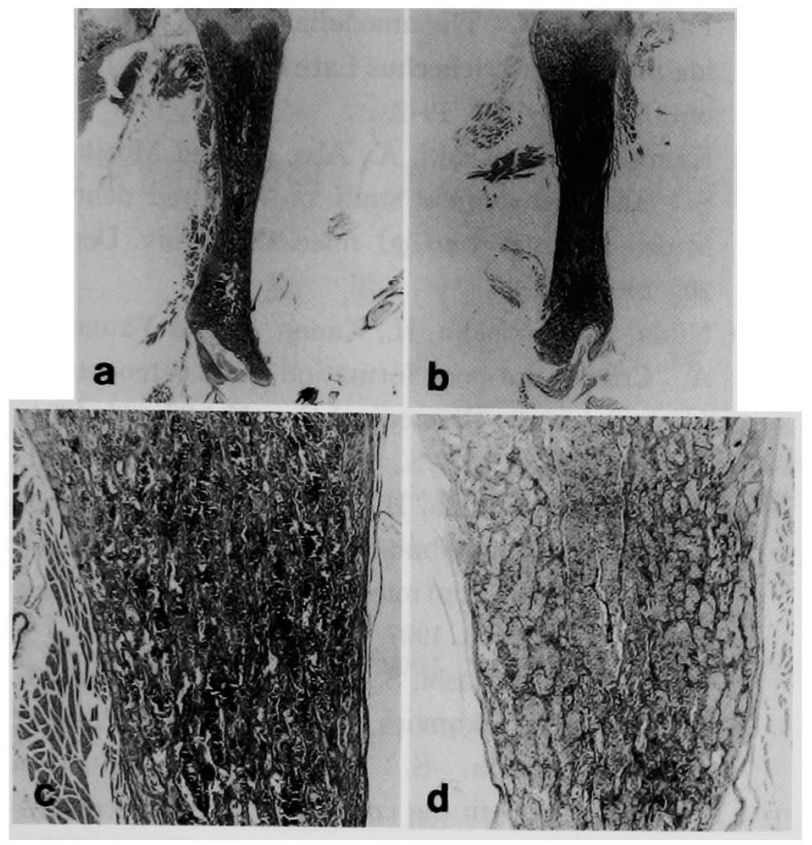

Fig. 4 Micrograph of the femur of both F3-op/op and B6C3Fe- op/op mice stained by H. E.

a : The femur of the F3-op/op mouse. (original magnification : $\times 2.5)$

$\mathrm{b}:$ The femur of the $\mathrm{B} 6 \mathrm{C} 3 \mathrm{Fe}-\mathrm{op} / \mathrm{op}$ mouse. (original magnification : $\times 2.5$ )

c : High magnification of the metaphysis in Fig. 4 a. (original magnification : $\times 20$ )

d : High magnification of the metaphysis in Fig. $4 \mathrm{~b}$. (original magnification : $\times 20$ )

tion $^{3,17,18)}$. Begg, et al. ${ }^{19)}$ reported that a hematopoietic system has the capacity to use alternative mechanisms to compensate for the absence of CSF-1 in $o p /$ $o p$ mice. A recent study revealed that two growth factors, vascular endothelial growth factor (VEGF) and placenta growth factor (PIGF), induce the osteoclasts in the $O p / O p$ mice, suggesting that osteoclast differentiation in the op mice is not mediated by the $\mathrm{CSF}^{-1}$ receptor ${ }^{20)}$. It is considered that the mechanism of osteoclast development is more complicated in op mice. In order to study the effects of osteoclast deficiency on the ankylosis process of tooth eruption in op mice, detecting the genotype at stages prior to the first appearance of the morphological abnormalities will be required. Since an enormous amount of murine genetic information is available, the genotype of a target mutation gene can easily be detected using
MIT markers ${ }^{21,22)}$. In this study, genotyping of the heterogenous osteopetrotic mice was performed using five MIT markers, D3Mit11, 75, 101, 102 and 189 that are closely linked to the $o p$ locus (Table 1 ). As shown in Fig. 3, polymorphism can easily be detected using PCR for D3Mit11 and D3Mit101. Based on the SSLP typing data using $\mathrm{PCR}$, the hypothesis genotypes of F2 and F3 mice were compared with their phenotype. Although it does not enable visual differentiation between $o p /+$ and $+/+$ genotypes, we could make a clear distinction between the two genotypes using the five MIT markers. Indeed, the homozygous $o p / o p \mathrm{~F} 3$ mice were obtained by the hypothesis mating of F2 mice (Fig. 2). These findings suggest that it is possible to detect the three genotypes of the op gene without a complicated molecular process.

Our histological study was carried out to compare the histopathological changes in the femur in F3-op/ $o p$ mice with $\mathrm{B} 6 \mathrm{C} 3 \mathrm{Fe}-o p / o p$ mice. The major skeletal metabolic changes in $\mathrm{B} 6 \mathrm{C} 3 \mathrm{Fe}-o p / o p$ mice are an increase in bone matrix formation and cytological evidence for a reduction in remodeling. Histopathological studies revealed that the F3-op/op mice showed similar femur bone structures to those of $\mathrm{B} 6 \mathrm{C} 3 \mathrm{Fe}-o p / o p$ mice.

In conclusion, this study suggests that genotyping of the heterogenous osteopetrotic mice using microsatellite markers is a powerful technique for investigating the mechanism of osteoclast development and genetic studies of osteopetrosis.

\section{Acknowledgements}

We are grateful to Dr. Norihisa Inuzuka (Department of Anatomy, the University of Tokyo) and Dr. Hiroyuki Okada (Department of Pathology, Nihon University School of Dentistry at Matsudo) for their valuable advice on this study. This work was supported by a grant from research for the Frontier Science (The Ministry of Education, Science, Sports and Culture of Japan).

\section{References}

1) Marks, S. C., Jr. and Lane, P.W. : Osteopetrosis, a 
new recessive skeletal mutation on chromosome 12 of the mouse. J. Hered. $67: 11-18,1976$.

2) Marks, S.C., Jr. : Morphological evidence of reduced bone resorption in osteopetrotic (op) mice. Am. J. Anat. 163 : 157-167, 1982.

3) Felix, R., Cecchini, M. G., Hofstetter, W., Elford, P. R., Stutzer, A. and Fleisch, H. : Impairment of macrophage colony-stimulating factor production and lack of resident bone marrow macrophages in the osteopetrotic op/op mouse. J. Bone Miner. Res. 5: 781-789, 1990.

4) Sato, Y., Okada, H., Sakae, T. and Yamamoto, H. : Bone structure in op/op mice as revealed by backscatter imaging. J. Dent. Res. $74: 567,1995$.

5) Sato, Y., Okada, H., Sakae, T. and Yamamoto, H. : Structure and composition of bone in osteopetrotic (op/op) mice. J. Dent. Res. 76 : 1183, 1997.

6) Sato, Y. : Construction and histopathological study of a new osteopetrotic mouse strain. Jpn. J. Oral. Biol. 40 : 108-119, 1998.

7) Asada, Y., Takamori, K., Yamamoto, H. and Maeda, T. : Detection of the flanking MIT markers for the op gene on mouse chromosome 3. Ped. Dent. J. 10:29-32, 2000.

8) Nomura, R., Nakamura, H., Matsune, K., Shimizu, T., Asada, Y. and Maeda, T. : Detection of informative SSLP markers for searching a causative gene (s) of absence of the third molars in EL mice. Ped. Dent. J. 10:75-79, 2000.

9) Asada, Y., Varnum, D. S., Frankel, W. N. and Nadeau, J. H. : A mutation in the Ter gene causing increased susceptibility to testicular teratomas maps to mouse chromosome 18. Nature Genet. 6 : 363-368, 1994.

10) Dietrich, W. F., Miller, J. C., Steen, R. G., Merchant, M., Damron, D., Nahf, R., Gross, A., Joyce, D. C., Wessel, M., Dredge, R. D., Marquis, A., Stein, L. D., Goodman, N., Page, D. C. and Lander, E. S. : A genetic map of the mouse with 4,006 simple sequence length polymorphisms. Nature Genet. 7 : 220-245, 1994.

11) Matin, A., Collin, G. B., Asada, Y., Varnum, D., Martone, D. L. and Nadeau, J. H. : Simple sequence length polymorphisms (SSLPs) that distinguish MOLF/Ei and 129/Sv inbred strains of laboratory mice. Mamm. Genome 9: 668-670, 1998.

12) Eppig, J. T., Blake, J. A., Davisson, M. T. and Richardson, J. E. : Informatics for mouse genetics and genome mapping. Methods 14 : 179-190, 1998.
13) Fawcett, D. W. : The amedullary bones of the Florida manatee (Trichechus Latirostris). Am. J. Anatomy $71: 271-309,1942$.

14) Kanno, E., Yamasaki, A., Abe, M. and Morikawa, S. : Histopathological study on impaired dentition in osteopetrotic $(o p / o p)$ mice. Ohu Univ. Dent. J. 20:24-30, 1993.

15) Niida, S., Wakisaka, H., Kanno, E. and Yamasaki, A. : Cranial flat bone formation in the osteopetrotic (op/op) mouse. Biomedical Res. 15 : 37-44, 1994.

16) Kawata, T., Niida, S., Kawasoko, S., Kaku, M., Fujita, T., Sugiyama, H. and Tanne, K. : Morphology of the mandibular condyle in "toothless" osteopetrotic (op/op) mice. J. Craniofac. Genet. Dev. Biol. 17 : 198-203, 1997.

17) Yoshida, H., Hayashi, S., Kunisada, T., Ogawa, M., Nishikawa, S., Okamura, H., Sudo, T., Shultz, L. D. and Nishikawa, S.: The murine mutation osteopetrosis is in the coding region of the macrophage colony stimulating factor gene. Nature $\mathbf{3 4 5}$ : 442-444, 1990.

18) Felix, R., Cecchini, M. G. and Fleisch, H. : Macrophage colony stimulating factor restores in vivo bone resorption in the op/op osteopetrotic mouse. Endocrinology 127 : 2592-2594, 1990.

19) Begg, S. K., Radley, J. M., Pollard, J. W., Chisholm, O. T., Stanley, E. R. and Bertoncello, I. : Delayed hematopoietic development in osteopetrotic (op/op) mice. J. Exp. Med. 177 : 237-242, 1993.

20) Niida, S., Kaku, M., Amano, H., Yoshida, H., Kataoka, H., Nishikawa, S., Tanne, K., Maeda, N., Nishikawa, S. and Kodama, H. : Vascular endothelial growth factor can substitute for macrophage colony-stimulating factor in the support of osteoclastic bone resorption. J. Exp. Med. 19 : 293-298, 1999.

21) Copp, A. J., Checiu, I. and Henson, J. N. : Developmental basis of severe neural tube defects in the loop-tail (Lp) mutant mouse : use of microsatellite DNA markers to identify embryonic genotype. Dev. Biol. 165 : 20-29, 1994.

22) Dietrich, W. F., Miller, J., Steen, R., Merchant, M. A., Damron-Boles, D., Husain, Z., Dredge, R., Daly, M. J., Ingalls, K. A., O'Connor, T. J., Evans, C.A., DeAngelis, M.M., Levinson, D.M., Kruglyak, L., Goodman, N., Copeland, N.G., Jenkins, N.A., Hawkins, T.L., Stein, L., Page, D.C. and Lander, E.S. : A comprehensive genetic map of the mouse genome. Nature 380 : 149-152, 1996. 